\title{
Marriage, Pregnancy and Sexual Practices in University Female Students in Cartagena, Colombia
}

\author{
Esther P. Polo ${ }^{1}$, Ayda M. Cassas ${ }^{1}$, Natalia A. Senior ${ }^{1} \&$ Muna Hamdan ${ }^{1}$ \\ ${ }^{1}$ University of Cartagena, Cartagena de Indias, Colombia \\ Correspondence: Muna Hamdan R., University of Cartagena, Cartagena de Indias, Colombia. Tel: \\ 57-301-347-0024. E-mail: mhamdanr@unicartagena.edu.co
}

Received: November 19, 2018 Accepted: December 13, 2018 Online Published: December 23, 2018

doi:10.5539/gjhs.v11n1p141

URL: https://doi.org/10.5539/gjhs.v11n1p141

\begin{abstract}
Introduction: Sexuality went from being a taboo to a matter of human rights regarding intimacy, sexual and reproductive disputes. Maternity in university students may produce a greater effort in the academic commitment, as well as limiting the time and quality of the academic activities. However, when pregnancy occurs, it is only the woman who carries its risk, "single mom" burden and child care in most cases.

Objectives: To determine the number of marital union and the factors of exposure to pregnancy risk in university students of exact sciences programs in a public university of Cartagena.

Methods: A quantitative research, of a descriptive type, with a population composed of students enrolled in 3 professional programs of Exact and Natural Sciences of a public university in Cartagena, Colombia, was carried out. A two-stage sampling was done. An Outline of the social and demographic profile of the participants for research purpose was prepared. Natality and exposure to pregnancy risk questions were applied. Data was processed using Epi lnfo 7.0, quantitative analysis was made using central tendency measures and qualitative variables and categories that applied to the study.

Results: $26 \%$ of the 89 participating students were women and were on average of 20 years old with a SD of 2.23 . $63 \%$ belonged to the subsidized system of the Colombian Health System. $97 \%$ of the participants belonged to socioeconomic levels 1 and $2.94 \%$ of the participants declared heterosexual behavior. Regarding the number of people with whom they have had sexual intercourse throughout their lives, the range of one to two people was $28 \%$, while $18 \%$ answered that they have had coital encounters with three or more people. $16 \%$ of the participants said they felt pressured by some friends to start their sexual relations. $56 \%$ of the surveyed reported having vaginal sex, of which $47 \%$ have performed this practice without the use of a condom. In the same way, $19 \%$ practiced anal sex, where $9 \%$ of them did not use condoms.
\end{abstract}

Conclusion: It is necessary to develop initiatives in the academic context that embraces the guidelines developed by WHO and UNFPA regarding sexual life and sexuality.

Keywords: marital relationship, adolescent, youth, pregnancy (MeSH)

\section{Introduction}

The contemporary world has experienced great transformations, within which those are referring to sexuality; it went from being a taboo in many parts of the world to a matter of human rights regarding intimacy, sexual and reproductive disputes. It represents a subject of interest in the agendas of international health agencies as well as economic and multilateral organizations, mainly due to the adverse effects in terms of sexually transmitted diseases, unplanned pregnancies, school dropout, female poverty, and maternal-perinatal mortality.

Although fertility rates have decreased worldwide due to the fact that higher rates of women are entering the workforce; however, the greatest challenges that we face today are, the decrease of early marriage in adolescents, the decrease of risk determinants such as unprotected sexual relations and the non-use of contraceptives, the lack of programs and initiatives that not only educate about physiological aspects, but cover social, gender and empowerment features, and emotional intelligence, considering that in 2015, approximately 14.5 million deliveries of adolescent mothers were registered in 156 countries (OMS, 2018). In developing countries, the unmet need for family planning services affects 12.8 million adolescents, (UNFPA, 2016), every year a total of 89 million unplanned pregnancies are registered in developing countries, 48 million abortions, 10 million spontaneous 
abortions, and 1 million cases of stillbirths (UNFPA, 2017).

Maternity in adolescents and university students is also a problem in developed countries. In the United States, a study shows that university students are increasingly involved in sexual relations at risk of conceiving. However, when pregnancy occurs, it is only the woman who carries its risk and "single mom" burden and child care (Brown \& Amankwaa, 2007).

Maternity in university students may produce a greater effort in the academic commitment, as well as limiting the time and quality of the academic activities. Although, paradoxically Miller and Arvizu (2016) show that some young women report experiencing a new attitude towards life when becoming mothers, whether the pregnancy was planned or not, this new attitude generates in them a high degree of maturity and focus, to the point of considering their children as their only true argument to excel each day. Other studies, such as those of Caraballo Z (2007) show that "The experience of combining these two roles results in a hectic life where both roles come into conflict."

Moreover, in Colombia, it is important to highlight the increasing rate of pregnancies in students and adolescents, which is related to an extension of the reproductive period of women due to the early age of menarche, the elongated period of risk exposure to pregnancy with respect to the early start of sexual relations, the steadiness of their first couple relationship, and the increasing tendency to new couples and family re-conformation. National Survey of Demography and Health (ENDS, 2015).

\subsection{Objective}

To determine the number of marital union and the factors of exposure to pregnancy risk in university students of exact sciences programs in a public university of Cartagena.

\section{Methodology}

A quantitative research, of a descriptive type, with a population composed of students enrolled in 3 professional programs of Exact and Natural Sciences (Mathematics, Chemistry and Biology) of a public university in Cartagena Colombia.

A two-stage sampling was carried out, where the initial groups were first year students (1st 2 nd semester of each program), the number of students was established by proportional allocation and the established inclusion criteria were:

- Students over 18 years of age

- Students who are enrolled and active in their first year face-to-face programs

- Students who are willing to participate and sign the informed consent of the research

Out of the total number of students that were studied, 32 individuals met the criteria.

\subsection{Instruments}

Outline of the social and demographic profile of the participants for research purposes, was prepared by the study team.

- Natality and exposure to pregnancy risk: Section 6 of the National Health Survey (ENDS 2015) questions from number 600 to 650 . A survey with questions of multiple choice answers, providing information on relationship history, which accounts for the various ways in which pairs are set up, and reveals the plurality and diversity of the sexual and reproductive life of the Colombian population.

A data entry process was carried out by means of the surveys using the Epi lnfo 7.0 program and the database was designed from which the expected statistics will be obtained, the quantitative analysis was made using central tendency measures and qualitative variables and categories that applied, the information obtained was presented in tables.

\subsection{Ethical Considerations}

This study followed all the procedures established in the resolution, No. 008430 OF 1993 of the Colombian Ministry of Health, Title II of the ethical aspects of research in human beings and the professional deontological code.

\section{Results and Discussion}

\subsection{Sociodemographic Profile of the Participants}

$26 \%$ of the 89 students enrolled in the first year in the programs of exact sciences were women. This low incidence 
of the female population enrolled in these programs can be explained by Herrera, I. et al. (2018) who describes that "in programs like these whose knowledge is ascribed to the hard sciences; the male student prevails. Other studies show that there is discrimination, exclusion and segregation of men and women who are inserted in professions considered as feminine and masculine whose spaces and activities are considered mostly generic attributes (Martinez \& Mora, 2018).

The students who participated in the study were, on average, 20 years old with a $\mathrm{SD}=2.23$ age classified according to the World Health Organization as young adults (OMS), being at this stage where risk behaviors are most intense.

Regarding the academic program, 53\% (17) of the women surveyed belonged to mathematics, the remaining percentage corresponded to the chemistry and biology programs, of I and II semester being $40 \%$ and $60 \%$ respectively.

Regarding religious belief, we observed a great proportion of Catholic students $44 \%$ (14). Religion, as a cultural component, modifies the attitudes of people generating transformations of sexual-social behaviors that provoke behavioral differences within the practitioners of each religion; however, in this study this variable had no important connection (Martinez, Parada \& Duarte 2013; Kellogg, Rosenbaum, Dweck, \& Millheiser, 2014).

Furthermore, 63\% (20 students) belonged to the subsidized system of the Colombian health system, in addition, almost all of the participants (97\%) belonged to socioeconomic levels 1 and 2, which are those with the least economic capacity (See Table 1).

Regarding sexual orientation, $94 \%$ declared heterosexual behavior. These results are similar to the one found by Zambrano, Tuscan \& Gil (2015) in their study with university students, where the most predominant sexual orientation was heterosexual with $83 \%$, and to a lesser extent, bisexual and homosexual orientation with $7 \%$.

\subsection{Nuptiality and Risk to Pregnancy}

In the study, $88 \%$ (28) of the university students surveyed are single, that is, they do not have a stable marital bond with a couple, and only $6 \%$ (2) have children, a result different to that found by Coschiza, Fernandez, Redcozub, Nievas and Ruiz (2016) where "87\% of their university participants were single and one of four students had children".

The phenomenon of non-coexistence with the couple of the moment is linked to patterns of cultural change; Before, the parents supervised with great rigor their daughters whereabouts while growing up, since it implied matters of reputation and honor to guard the sexuality of their young girls, in such a way that the boys who befriended them had to have the permission of their parents, secret sexual or sentimental relationships were forbidden and punished with marriage; it could be thought that the way to maintain intimate relationships with their partners in the private sphere is not only a form of exercise of procreative sexual rights by young women, but a form of emancipation from parental supervision. Although, it is important to emphasize that gender inequality and the disparity in the enjoyment of sexual and reproductive health and rights are two fundamental aspects that do not receive enough attention. So that women and girls will remain trapped in a vicious circle of poverty, reduced capacities, and impossibility to exercise their human rights and develop their potential - especially in developing countries where the differences are most pronounced (UNFPA, 2017).

Regarding the question "With how many people have you had sex in the last 12 months?" $25 \%$ (8) of the participants answered only one person and in a smaller proportion $6 \%$ (2) were with two people. Likewise, they were asked; with how many people have had sexual intercourse throughout their lives, the range of one to two people corresponded to $28 \%$ (9), and $18 \%$ (6) answered that they have had coital encounters with three or more people (See Table 2). Hurtado et al. (2017) carried out a study about the link between multiple couples and early initiation of sexual relations, he found that there is statistically significant relationship, which makes young people vulnerable to acquire sexually transmitted infections, as well as unwanted pregnancy. In the same way Melo et al. (2016) in their research also found a relation with the number of sexual partners in university students with the frequency of HPV and Chlamydia trachomatis. The above clearly evidences the possible risks that university students may have.

\subsection{Conditioners of Risk}

Group pressure: $16 \%$ of the participants said they felt pressured by some friends to start their sexual relations. This is related to what was found by Holguín et al. (2013) in his research; where they associated the influence of peers or friends in decision-making, with the early onset of sexual activity among adolescents. Similarly, the University of Utrecht in collaboration with the Psychiatric Institute of New York (year), through a meta-analysis, concluded that one of the main reasons why adolescents have an early start in their sexual relations is because their friends do 
so.

For this research, 58 studies from 15 countries were analyzed about the sexual behavior of almost 70,000 adolescents, mainly considering three variables: descriptive norms (How others act?; What they do?), norms of approval (What do group values have to do with?; Does my group support me doing this?). And the third variable: group pressure. All the variables had an extremely noticeable influence (Portalatin, 2015). In the same way, Martinez et al. (2013) found that "women are more prone to be influenced by their group". That is why; it is known that among young people, friendship relations may affect their adaptation to the social environment in which they live, copying their social attitudes and behaviors (Portalatin, 2015). What Navarrete, Castel, Romanos \& Bruna (2017) imply to the lack of sexual health empowerment, and evidences the great susceptibility to peer pressure at this age.

Another risk factor in this study is the age of initiation of sexual intercourse, the average age was 16 years old SD $=1.58$ years. Hurtado M. et al. (2017) found similar results, where the average age of the beginning of sexual intercourse for university females in Mexico was 17 years. Also, in Colombia, according to PROFAMILIA's report (2016), the percentage of women aged between 20 and 24 years who had their first sexual relationship, was before their 15 years of age. Thus, premature sex represents a public health problem due to the consequences that, in addition to unwanted pregnancies and STDs, brings with it family, economic and social problems (Mendoza, Claros, \& Peñaranda, 2016) in addition, it is a "big risk factor in HPV infections" (Hurtado \& Olvera, 2017).

The sexual curriculum of the couple with whom they initiate their sex life including their age can be considered another risk factor, where the average age of the person with whom they had their first sexual encounter was 20 years old and $60 \%$ of those were males. This is related to that reported by the II National Survey of Sexual and Reproductive Health of Costa Rica, (2016), which shows that the beginning of sexual life in both men and women is early and to a large extent occurs before adulthood. However, it can be clearly seen that, in the case of this study, the beginning of sexual life was established between minors and adults, which leads to disadvantaged and vulnerable conditions for the child in this case the females. Hence, usually before the age of 25, the proportion of men who have had sexual intercourse is always greater than that of women, this means that the men already have sexual curricula, the women or the girls, are just about to start.

Non use of condoms in the first sexual relationship: The use of condoms is a good practice, however, it was found that only $34 \%$ of couples used a condom in their first intercourse, this agrees with what was found by Martínez et al. (2013), where "the percentage of people who used condoms in their first sexual relationship was low". This may be due to the fact that negotiation in the use of condoms is more limited due to scarce information and the lack of development of sexual autonomy in adolescents (ENDS 2015). This is important because the use of the condom in the coital debut is a positive marker of sexual behavior; since it is expected that if a condom is used in the first encounter, there is a greater probability of continuing to use it in the next relationships, which leads to a reduction of STDs/STIs.

Likewise, $56 \%$ of the surveyed reported having vaginal sex, of which $47 \%$ have performed this practice without the use of a condom. In the same way, $19 \%$ practiced anal sex, where $9 \%$ of them did not use condoms. This is related to an investigation carried out in university students in Medellin, where $71 \%$ had vaginal sex in the last six months, and 12\% said they had had anal sex, besides, they stated that they were performed without protection (Morales, Mesa, Arboleda, \& Segura, 2014). This clearly reflects the risks to which newbie students are exposed to, in addition to, unwanted pregnancies, and in the worst cases to Sexually Transmitted Diseases.

The educational level attained by the young women in their beginning of active sexual life, is determinant in the possibility of increasing or decreasing the risks of motherhood, as it has been demonstrated that the educational level of women is inversely proportional to fertility (Meza \& Junca, 2011). That is why access to higher education, as well as obtaining greater educational achievements makes marriage and conception a less attractive option. However, although women (and men) with higher education show later marital patterns, this relationship operates mainly as a function of the different periods of permanence within the education system (Miller \& Arvizub, 2016).

Adolescent and university motherhood is a stressor, a reason for changes in the family and social dynamics of the youth, it is no secret that "unexpected" motherhood in the academic year often interferes with the studies, Miller and Arvizuc (2016) found in their research that women with children in college require more average time to complete upper secondary education. In this case, being single and not having children could favor the permanence and completion of the university studies in a timely and satisfactory manner. However, studies that deepen this affirmation would be required. It is important not to ignore that the adverse effects of adolescent motherhood also extend to the health of their infants. Perinatal deaths are 50\% higher among babies born to mothers under the age of 20 years. Newborns of adolescent mothers are more likely to have low birth weight, with long-term risks (WHO, 
2011).

\section{Conclusions}

Natality is not experienced by young women with marriage or free union, but it is evident as active marital life with non-cohabiting couples.

Young women, although they are developing university studies, experience pressure from the group, they have an active sexual life with the non-use of contraceptives and condoms, which conditions the exposure to risk of pregnancy and other adverse results of unsafe sexual practices.

It is necessary to develop initiatives in the academic context that embraces the guidelines developed by WHO and UNFPA, such as limiting marriage before the age of 18 , creating understanding and support to reduce pregnancies before the age of 20, increase the use of contraception, reduce sexual relations under coercion, and others, for the prevention of early pregnancy and adverse reproductive outcomes.

\section{Competing Interests Statement}

The authors declare that there are no competing or potential conflicts of interest.

\section{References}

Bahamón Muñetón, M. J., Vianchá Pinzón, M. A., \& Tobos Vergara, A. R. (2014). Prácticas y conductas sexuales de riesgo en jóvenes: una perspectiva de género. Psicología desde el Caribe, 31(2), 327-353. https://doi.org/10.14482/psdc.31.2.3070

Brown, R. L. (2007). College females as mothers: Balancing the roles of student and motherhood. ABNF Journal, 18(1), 25. Retrieved from https://www.ncbi.nlm.nih.gov/pubmed/18402354

Caraballo, Z. (2007). Entre Pa-ales y Libros: La Experiencia de ser Madre Soltera y Estudiante del Recinto WordPress. https://zcaraballo.wordpress.com/2007/04/10/mi-propuesta-de-investigacion/

Cristóbal Coschiza, C., Martín Fernández, J., \& Gapel Redcozub, G. (2016). Características socioeconómicas y rendimiento académico. El caso de una universidad argentina. Retrieved from http://www.redalyc.org/pdf/551/55146042003.pdf

Herrera-Zuleta, I. A., Reyes-Salazar, J. F., Rojas-Velasco, K. P., Tipán, M. L., Torres-López, C. A., Trujillo, L. M. V., \& Zemanate-Ordoñez, L. F. (2018). Salud sexual reproductiva en estudiantes universitarios: conocimientos y prácticas. Revista Ciencia y Cuidado, 15(1), 58-70. Retrieved from http://revistas.ufps.edu.co/ojs/index.php/cienciaycuidado/article/view/1233/118

Holguín, Y. P., Mendoza, L. A., Esquivel, C. M., Sánchez, R., Daraviña, A. F., \& Acuña, M. (2013). Factores asociados al inicio de la actividad sexual en adolescentes de Tuluá, Colombia. Revista chilena de obstetricia y ginecología, 78(3), 209-219. https://doi.org/10.4067/S0717-75262013000300007

de Mendoza Zabalgoitia, M. T. H., \& Méndez, J. O. (2017). Características del debut sexual en una población de jóvenes mexicanos. Revista Electrónica de Psicología Iztacala, 20(4), 1602. http://www.revistas.unam.mx/index.php/repi/article/view/62827

de Mendoza Zabalgoitia, H., Teresa, M., Veytia López, M., Guadarrama Guadarrama, R., \& González-Forteza, C. (2017). Asociación entre múltiples parejas sexuales y el inicio temprano de relaciones sexuales coitales en estudiantes universitarios. Nova scientia, 9(19), 615-634. https://doi.org/10.21640/ns.v9i19.849

II Encuesta Nacional de Salud Sexual Reproducitva. Costa rica. http://ccp.ucr.ac.cr/documentos/portal/Informe-2daEncuesta-2015.pdf

Kellogg, S. R. (2014). Sexual health and religion: A primer for the sexual health clinican. Sex Med, 7-18. https://www.ncbi.nlm.nih.gov/pubmed/24989443

Martínez, J., Parada, L., \& Duarte, K. (2013). Uso de condón en la primera relación sexual en estudiantes entre 18 y 26 a-os de una universidad pública. MedUNAB, 16(3), 112-117 http://basesdedatos.unicartagena.edu.co:2065/eds/pdfviewer/pdfviewer?vid=3\&sid=ae999040-f9f7-48fe-a6 c6-e24a4e4c16cc\%40sessionmgr4010

Martínez, K., \& Mora, M. (2018). Tienen sexo las profesiones. Hombres y mujeres en profesiones femeninas y masculinas, el caso de los enfermeros y las ingenieras mecánicas electricistas (Tesis doctoral). San Luis Potosí, México. Retrieved from http://biblio.colsan.edu.mx/tesis/MartinezMendezKarlaIrene.pdf 
Melo, A., Lagos, N., Montenegro, S., Orellana, J. J., Vásquez, A. M., Moreno, S., ... \& Fonseca-Salamanca, F. (2016). Virus papiloma humano y Chlamydia trachomatis según número de parejas sexuales y tiempo de actividad sexual en estudiantes universitarias en la Región de La Araucanía, Chile. Revista chilena de infectología, 33(3), 287-292. https://doi.org/10.4067/S0716-10182016000300006

Mendoza Tascón, L. A., Claros Benítez, D. I., \& Peñaranda Ospina, C. B. (2016). Actividad sexual temprana y embarazo en la adolescencia: estado del arte. Revista chilena de obstetricia y ginecología, 81(3), 243-253. http://dx.doi.org/10.4067/S071775262016000300012

Mesa Salamanca, C. A., \& Junca Rodríguez, G. A. (2011). Análisis de reducción de la fecundidad en Colombia: Modelo de determinantes próximos. Cuadernos de economía, 30(54), 127-150. Retrieved from http://www.scielo.org.co/scielo.php?script=sci_arttext\&pid=S0121-47722011000100006

Miller, D., \& Arvizu, V. (2016). Ser madre y estudiante. una exploración de las características de las universitarias con hijos y breves notas para su estudio. Revista de la educación superior, 45(177), 17-42. http://www.scielo.org.mx/scielo.php?script=sci_arttext\&pid=S018527602016000100017\&lng=es\&nrm=iso

Ministerio de salud, P. (2015). Encuesta Nacional de Demografía y Salud tomo II. Colombia. http://www.profamilia.org.co/docs/TOMO\%20II.pdf

Morales, S. A., Álvarez, O. L. A., \& Cardona, Á. M. S. (2014). Las prácticas sexuales de riesgo al VIH en población universitaria. Revista de Salud Pública, 16(1), 27-39. https://doi.org/10.15446/rsap.v16n1.30659

Navarrete Villanueva, D., Castel Feced, S., Romanos Calvo, B., \& Bruna Barranco, I. (2017). Influencia negativa de las redes sociales en la salud de adolescentes y adultos jóvenes: una revisión bibliográfica. Revista Psicología y Salud, 27(2).

Organización Mundial de la $\quad$ Salud. http://www.who.int/maternal_child_adolescent/documents/preventing_early_pregnancy/es/

Organización Mundial de la $\quad$ Salud. https://www.who.int/es/news-room/fact-sheets/detail/adolescent-pregnancy

Organización Mundial de la $\quad$ Salud. http://www.med-informatica.net/TERAPEUTICA-STAR/Nefropatias_InsuficienciaRenalCronica_GuiaAten cionMS2007_guiarenal02.pdf

Portalatínb, B. G. (2015). El mundo. El despertar de la Sexualidad. http://www.elmundo.es/salud/2015/04/29/553fbf1222601d5c228b457e.html

Profamilia. (2016). Informe profamilia. Colombia: profamilia. http://www.profamilia.org.co/docs/INFORME\%20PROFAMILIA\%202016\%20VERSION\%20MARZO\%2 016.pdf

UNFPA. (2016). Universal Access to Reproductive Health: Progress and Challenges. New York. https://www.unfpa.org/sites/default/files/sowp/downloads/UNFPA_PUB_2017_ES_SWOP_Estado_de_la_ Poblacion_Mundial.pdf

UNFPA. (2017). Recuperado el 11 de diciembre de 2018 de unfpa.org: https://lac.unfpa.org/es/news/unfpa-presenta-estado-de-la-poblaci\%C3\%B3n-mundial-2017 https://www.unfpa.org/es/swop-2017

UNFPA. (2018). unfpa.org. Recuperado el 10 de ABRIL de 2018, de unfpa.org: https://www.unfpa.org/es/swop

Zambrano-Plata, G. E., Toscano-Moros, J. P., \& Gil-Marles, J. (2015). Actitudes sexuales en adolescentes estudiantes universitarios. Revista ciencia y cuidado, 12(1), 93-104. 


\section{Appendix}

Table 1. Distribution according to sociodemographic characteristics of the students surveyed of exact and natural sciences. Cartagena 2018.

\begin{tabular}{lll}
\hline Academic Program & $\mathbf{N}$ & $\mathbf{\%}$ \\
\hline Biology & 7 & $21.96 \%$ \\
Chemistry & 8 & $25.00 \%$ \\
Mathematics & 17 & $53.04 \%$ \\
\hline Semester & $\mathbf{N}$ & $\mathbf{\%}$ \\
\hline I & 13 & $40.62 \%$ \\
II & 19 & $59.38 \%$ \\
\hline Religion & $\mathbf{N}$ & $\mathbf{\%}$ \\
\hline Catholic & 14 & $43.75 \%$ \\
Protestant & 10 & $31.25 \%$ \\
Other & 6 & $18.75 \%$ \\
Doesn't practice any & 2 & $6.25 \%$ \\
\hline Health System Regimen & $\mathbf{N}$ & $\mathbf{\%}$ \\
\hline Contributive & 12 & $37.50 \%$ \\
Subsidized & 20 & $62.50 \%$ \\
\hline Socioeconomic Level & $\mathbf{N}$ & $\mathbf{\%}$ \\
\hline Level 1-2 = bellow US $\$ 350$. & 16 & $50.00 \%$ \\
Level 3-4= between US $350-700$ & 15 & $46.88 \%$ \\
Level 5-6= a little over US $\$ 800$ & 1 & $3.13 \%$ \\
\hline
\end{tabular}

Source: Study survey

\section{Nuptiality}

Table 2. Distribution according to nuptiality of the students surveyed of exact and natural sciences. Cartagena 2018.

\begin{tabular}{lll}
\hline Marital Status & $\mathbf{N}$ & $\mathbf{\%}$ \\
\hline Single & 28 & $87.50 \%$ \\
Free union & 4 & $12.50 \%$ \\
\hline Children & $\mathbf{N}$ & $\mathbf{\%}$ \\
\hline Yes & 2 & $6.25 \%$ \\
No & 30 & $93.75 \%$ \\
\hline
\end{tabular}

With how many different people have you had sex in the last 12 months?

\begin{tabular}{lll}
\hline No. of sex partners & $\mathbf{N}$ & $\mathbf{\%}$ \\
\hline 1 & 8 & $25.00 \%$ \\
2 & 2 & $6.25 \%$ \\
\hline
\end{tabular}


With how many different people have you had sex throughout your life?

\begin{tabular}{lll}
\hline No. of sex partners & $\mathbf{N}$ & $\mathbf{\%}$ \\
\hline $1-2$ & 9 & $28.08 \%$ \\
$3-4$ & 3 & $9.36 \%$ \\
$5-6$ & 3 & $9.36 \%$ \\
\hline
\end{tabular}

\section{Exposure to the Risk of Pregnancy}

Table 3. Distribution according to natality of the students surveyed of Exact and Natural Sciences. Cartagena 2018

\begin{tabular}{lll}
\hline Sexual orientation & Frequency & $\mathbf{\%}$ \\
\hline Heterosexual & 30 & $93.75 \%$ \\
Bisexual & 1 & $3.13 \%$ \\
Homosexual & 1 & $3.13 \%$ \\
Total & $\mathbf{3 2}$ & $\mathbf{1 0 0 . 0 0 \%}$ \\
\hline
\end{tabular}

\begin{tabular}{lllll}
\hline Have you had sex: & Yes & No & NA/NR \\
\hline 1. & Vaginal sex & $56.25 \%(18)$ & $37.50 \%(12)$ & $6.25 \%(2)$ \\
2. Have you had vaginal sex with no protection? & $46.88 \%(15)$ & $15.62 \%(5)$ & $37.50 \%(12)$ \\
3. Have you had anal sex? & $18.76 \%(6)$ & $68.75 \%(22)$ & $12.49 \%(4)$ \\
4. Have you had anal sex with no protection? & $9.36 \%(3)$ & $9.36 \%(3)$ & $81.28 \%(26)$ \\
\hline
\end{tabular}

Total: $100.00 \%$

1. How old were you when you had your first sexual 16.28 years $\mathrm{DE}= \pm 1,58$ years
intercourse:

\begin{tabular}{lll}
\hline 2. & Peer pressure to start sexual relations & $15.60 \%(5)$ \\
\hline 3. & The first time you had sex, your partner used a condom & $34.32 \%(11)$ \\
\hline & $\begin{array}{l}\text { gender of the person with whom you had your first } \\
\text { sexual relationship }\end{array}$ & $\begin{array}{l}\text { male: } 59.28 \%(19) \\
\text { female: } 3.12(1) \\
\text { NA/NR: } 37.60 \%(12)\end{array}$ \\
\hline 5. & $\begin{array}{l}\text { Age of the person with whom you had your first sexual } \\
\text { relationship }\end{array}$ & 19.85 years $\mathrm{SD}= \pm 3.83$ years \\
\hline
\end{tabular}

With how many different people have you had sex in the last 12 months?

\begin{tabular}{lll}
\hline How many? & $\mathbf{N}$ & $\%$ \\
\hline 1 & 8 & $25.00 \%$ \\
2 & 2 & $6.25 \%$ \\
\hline
\end{tabular}


With how many different people have you had sex throughout your life?

\begin{tabular}{lll}
\hline How many? & $\mathbf{N}$ & $\mathbf{\%}$ \\
\hline 1 & 5 & $15.60 \%$ \\
2 & 4 & $12.48 \%$ \\
3 & 2 & $6.25 \%$ \\
4 & 1 & $3.12 \%$ \\
5 & 1 & $3.12 \%$ \\
6 & 2 & $6.25 \%$ \\
\hline & & \\
\hline How many? & $\mathbf{N}$ & $\mathbf{\%}$ \\
\hline $1-2$ & 9 & $28.08 \%$ \\
$3-4$ & 3 & $9.36 \%$ \\
$5-6$ & 3 & $9.36 \%$ \\
\hline
\end{tabular}

\section{Copyrights}

Copyright for this article is retained by the author(s), with first publication rights granted to the journal.

This is an open-access article distributed under the terms and conditions of the Creative Commons Attribution license (http://creativecommons.org/licenses/by/4.0/). 